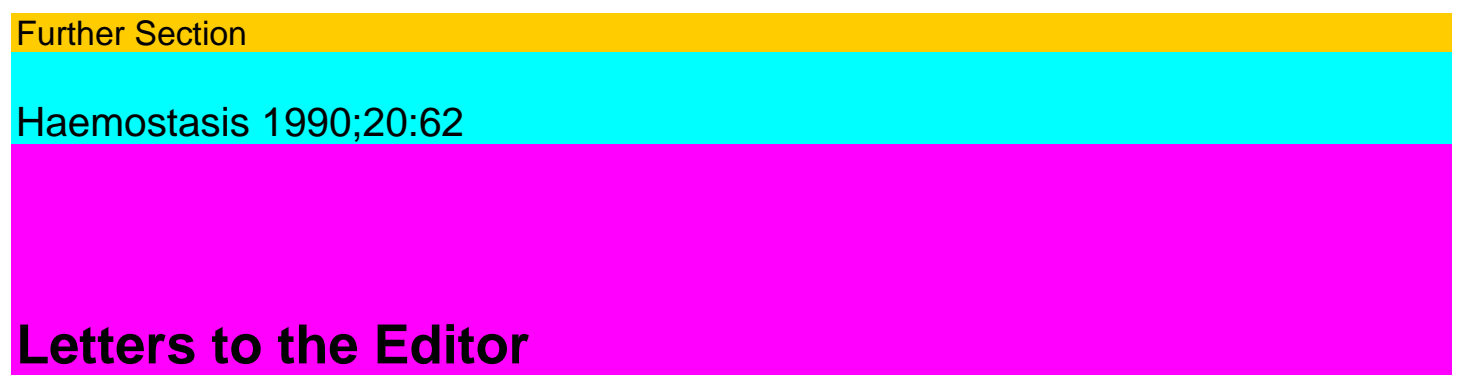

\title{
J. Benveniste
}

J. Benveniste, MD, Institut de la Santé et de la Recherche Médicale, INSERM U 200, Université Paris-Sud, Immunopharmacologie de ГAllergie et de, Пnfiammation, 32, rue des Carnets, F-92140 Clamart (France)

I wish to comment on two articles on paf-acether published in the May/June issue of Haemostasis, by Ostermann et al. [1] and by Hofmann et al. [2]. These papers are remarkable in that the reference lists comprise about $99 \%$ American references. It is very concerning that European authors exhibit so little concern for the international recognition of European research. If, on a mediator that was discovered and maintained afloat by a European group before internationalisa-tion of the theme, European authors do not quote European literature, when will they do it? There is then no need to complain that European research is poorly treated in international congresses and that on the whole the position of European research is not what it should be. Collaborating on an equal basis with American colleagues is a sound policy. But this must not be confused with Coca-colonisation, especially when knowing that our American colleagues only respect those who hold calmly but firmly their position. Should the authors fail to pay attention to these matters, it should be the duty of the editorial board and the referees to enforce a few basic rules aimed at protecting the interests of European research.

References

Ostermann G, Kostner GM, Gries A, et al: The contribution of individual lipoproteins to the degradation of platelet-activating factor in human serum. Haemostasis 1989;19:160-168.

Hoffmann B, Rühling K, Spangenberg P, et al: Enhanced degradation of plateletactivating factor in serum from diabetic patients. Haemostasis 1989;19:180-184. Note added in proof: The disease hits French groups as well. See Randriamampita and Trautmann, FEBS Lett. 1989;249:199-206. They at least have the excuse of not recognizing a prophet in their own country. Strikingly, most use my 1972 and by now obsolete, fuzzy, incorrect but American-enforced 'platelet-activating factor', instead of the modern, logical and handy 'paf-acether (paf)'. 